ETNIK : Jurnal Ekonomi - Teknik

ISSN: 2808-6694 (Online);2808-7291 (Print)

Jurnal Homepage https://etnik.rifainstitute.com

\title{
SISTEM INFORMASI ABSENSI KEPEGAWAIAN BERBASIS WEB PADA PT PRADA BANGUN PERSADA
}

\author{
Yusuf Wibisono
}

STMIK Muhammadiyah Jakarta

\section{Informasi Artikel}

Histori Artikel:

Diterima

Direvisi

06 Desember 2021

14 Desember 2021

Diterbitkan 20 Desember 2021

Email Author:

yusupwibisono21@gmail.com

\begin{abstract}
PT. Prada Bangun Persada is a branch company that has a head office in the Jakarta area which is engaged in the field of Sports Equipment which has staff that must be managed properly. In this management, the company makes an annual performance report, one of which contains a report on staffing. PT. Prada Bangun Persada has several sections in the organizational structure, one of which is the general responsibility section and the finance section. The general responsibility department and the finance department in this company do not yet have an efficient personnel information system application and are still processing data manually, resulting in various obstacles. Constraints experienced by the general person in charge are still using paper forms in making employee data and submitting employee letters so that they are less efficient and always provide paper forms. Then the storage of these letters still uses their respective folders based on the type of letter so that it is difficult to access and search for employee data and it is not safe if the storage is still using a folder and sometimes its validation is not handled properly. Then in the finance department in the employee payroll process, which still calculates and saves with Microsoft excel format files which causes low security and confidentiality of employee payroll data at risk of file damage if exposed to a virus and employees can easily access the file. This Personnel Information System uses a 2-step method. First, the data collection method was carried out in three ways, namely the observation method, the interview method and the literature study. Second, the system development method that will be used is the waterfall system development method, and uses UML (Unified Modeling Language) notation as tools.
\end{abstract}

Keyword- Information Systems, Personnel, UML

\begin{abstract}
ABSTRAK
PT. Prada Bangun Persada adalah perusahaan cabang yang mempunyai kantor pusat di daerah Jakarta yang bergerak di bidang Alat-alat Olahraga yang mempunyai kepegawaian yang harus
\end{abstract}


dikelola dengan baik. Di dalam pengelolaan tersebut, Di perusahaan Tersebut membuat laporan kinerja tahunan yang salah satunya berisi laporan tentang kepegawaian. PT. Prada Bangun Persada memiliki beberapa bagian dalam struktur organisasi yang salah satunya adalah bagian penanggung jawab umum dan bagian keuangan. Bagian penanggung jawab umum dan bagian keuangan di perusahaan ini belum memiliki aplikasi sistem informasi kepegawaian yang efisien dan masih melakukan pengolahan data secara manual sehingga terjadi berbagai kendala. Kendala yang dialami oleh bagian penanggung jawab umum yaitu masih menggunakan form kertas dalam membuat data pegawai dan pengajuan surat pegawai sehingga kurang efisien dan selalu menyediakan kertas formulir. Kemudian penyimpanan surat-surat tersebut masih menggunakan map masing-masing berdasarkan jenis surat sehingga mengalami sulitnya mengakses dan mencari data pegawai serta tidak aman jika penyimpanannya masih menggunakan map serta dalam validasinya terkadang tidak ditangani dengan baik. Kemudian di bagian keuangan pada proses proses penggajian pegawai yang masih menghitung dan menyimpan dengan file format Microsoft excel yang menyebabkan rendahnya keamanan dan kerahasiaan data penggajian pegawai yang beresiko rusaknya file apabila terkena virus dan dengan mudahnya pegawai dapat mengakses file tersebut. Sistem Informasi Kepegawaian ini menggunakan 2 tahap metode. Pertama, metode pengumpulan data dilakukan dengan tiga cara, yaitu metode observasi, metode wawancara dan studi pustaka. Kedua, metode pengembangan sistem yang akan digunakan adalah metode pengembangan sistem waterfall, serta menggunakan notasi UML (Unified Modelling Language) sebagai tools.

Kata Kunci - Sistem Informasi, Kepegawaian, UML

\section{PENDAHULUAN}

Seiring dengan perkembangan zaman, tiap individu maupun kelompok dituntut untuk beraktifitas seefisien dan seefektif mungkin guna mencapai hasil yang maksimal. Agar segala aktivitas dapat dijalankan secara efektif, terkadang teknologi menjadi suatu solusi yang tepat. Untuk itu, disinilah peran teknologi informasi dapat memudahkan segala aktivitas dalam berbagai bidang (Purnama et al. 2021).

Dengan adanya teknologi informasi yang dapat diaplikasikan dalam berbagai kehidupan manusia, pengguna teknologi informasi dapat memanipulasi data serta mendapatkan informasi secara aman dan mudah (Budiman 2017). Sebagai contoh dalam kegiatan perusahaan, teknologi informasi berperan penting dalam informasi dan pengelolaan data yang dimiliki perusahaan, dimana seharusnya data perusahaan dikelola secara aman. Dalam hal ini, teknologi sistem informasi kepegawaian merupakan suatu teknologi yang tepat untuk memudahkan kegiatan perusahaan dalam mengelola data tersebut (Devri Radistya 2014).

Perusahaan PT. Prada Bangun Persada adalah perusahaan cabang yang mempunya kantor pusat di daerah jakarta Pusat, dan salah satu Perusahaan Swasta yang bergerak di bidang. Alatalat Olahraga PT. Prada Bangun Persada memiliki beberapa bagian dalam struktur organisasi yang salah satunya adalah bagian penanggung jawab umum dan bagian keuangan. Bagian 
penanggung jawab umum dan bagian keuangan di perusahaan ini belum memiliki aplikasi sistem informasi kepegawaian yang efisien dan masih melakukan pengolahan data secara manual sehingga terjadi berbagai kendala.

Kendala yang dialami oleh bagian penanggung jawab umum yaitu masih menggunakan form kertas dalam membuat data pegawai dan pengajuan surat pegawai sehingga kurang efisien dan selalu menyediakan kertas formulir. Kemudian penyimpanan surat-surat tersebut masih menggunakan map masing-masing berdasarkan jenis surat sehingga mengalami sulitnya mengakses dan mencari data pegawai serta tidak aman jika penyimpanannya masih menggunakan map serta dalam validasinya terkadang tidak ditangani dengan baik.

\section{METODE}

\section{Teknik Pengumpulan data}

\section{Studi Pustaka}

Dilakukan pengumpulan data studi pustaka berupa jurnal penelitian, buku-buku database, web dan skripsi lulusan sebelumnya, serta mempelajari teori maupun karya ilmiah serupa atau berhubungan yang pernah dilakukan sebelumnya sebagai acuan terkait penelitian.

\section{Observasi}

Metode pengumpulan data dengan melakukan pengamatan secara langsung dan pencatatan mengenai bagaimana proses pengolahan data asset di PT Prada Bangun Persada.

\section{Wawancara}

Melakukan wawancara langsung pada kepala divisi PT Prada Bangun mengenai bagaimana keberlangsungan proses manajemen aset di perusahaan tersebut.

\section{Metode Pemodelan Sistem}

Metode pemodelan sistem yang dipakai adalah Unified Modeling Language (UML) yang merupakan bahasa visual untuk pemodelan dan komunikasi mengenai sebuah sistem dengan menggunakan diagram dan teks-teks pendukung (Agnitia LEstari, Tabrani, and Ayumida 2021). UML adalah salah satu standar bahasa yang banyak digunakan di dunia industri untuk mendefinisikan requirement, membuat analisis dan desain, serta menggambarkan arsitektur dalam pemrograman berorientasi objek (Sasmito 2017).

\section{Metode Pengembangan Sistem}

Metode pengembangan sistem yang diterapkan dalam penelitian ini adalah dengan pengembangan metode waterfall versi Ian Sommervile, metode waterfall merupakan model pengembangan sistem informasi yang sistematik dan sekuensial (Budi, Siswa, and Abijono 2017).

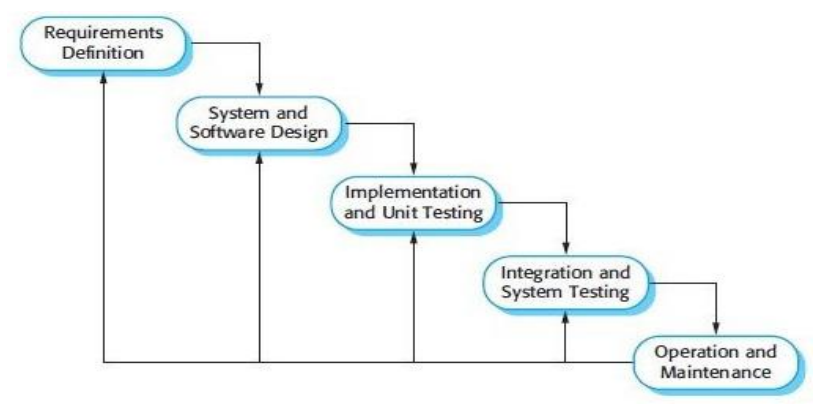




\section{Gambar 1. Tahapan Metode Waterfall versi Ian Sommerville (2011)}

\section{Metode Pengujian Pengembangan Sistem}

Pengujian terkait pengembangan sistem ini menggunakan metode Black box testing (Pengujian Kotak Hitam), yaitu menguji perangkat lunak dari segi spesifikasi fungsional tanpa menguji desain dan kode program (Pratama, Primawati, and Ariyani 2019). Teknik pengujian kotak hitam memungkinkan anda untuk membuat beberapa kumpulan kondisi masukan yang sepenuhnya akan melakukan semua kebutuhan fungsional untuk program. Pengujian kotak hitam bukan teknik alternatif untuk kotak hitam (Fajri 2016).

\section{HASIL DAN PEMBAHASAN}

\section{Analisis Sistem Yang Berjalan}

Analisa sistem yang sedang berjalan di PT Prada Bangun Persada dibuat dalam bentuk use case diagram, karena notasi ini dapat menggambarkan prosedur yang sedang berjalan. Sehingga dapat dijadikan sebagai bahan evaluasi dan pengembangan sistem.

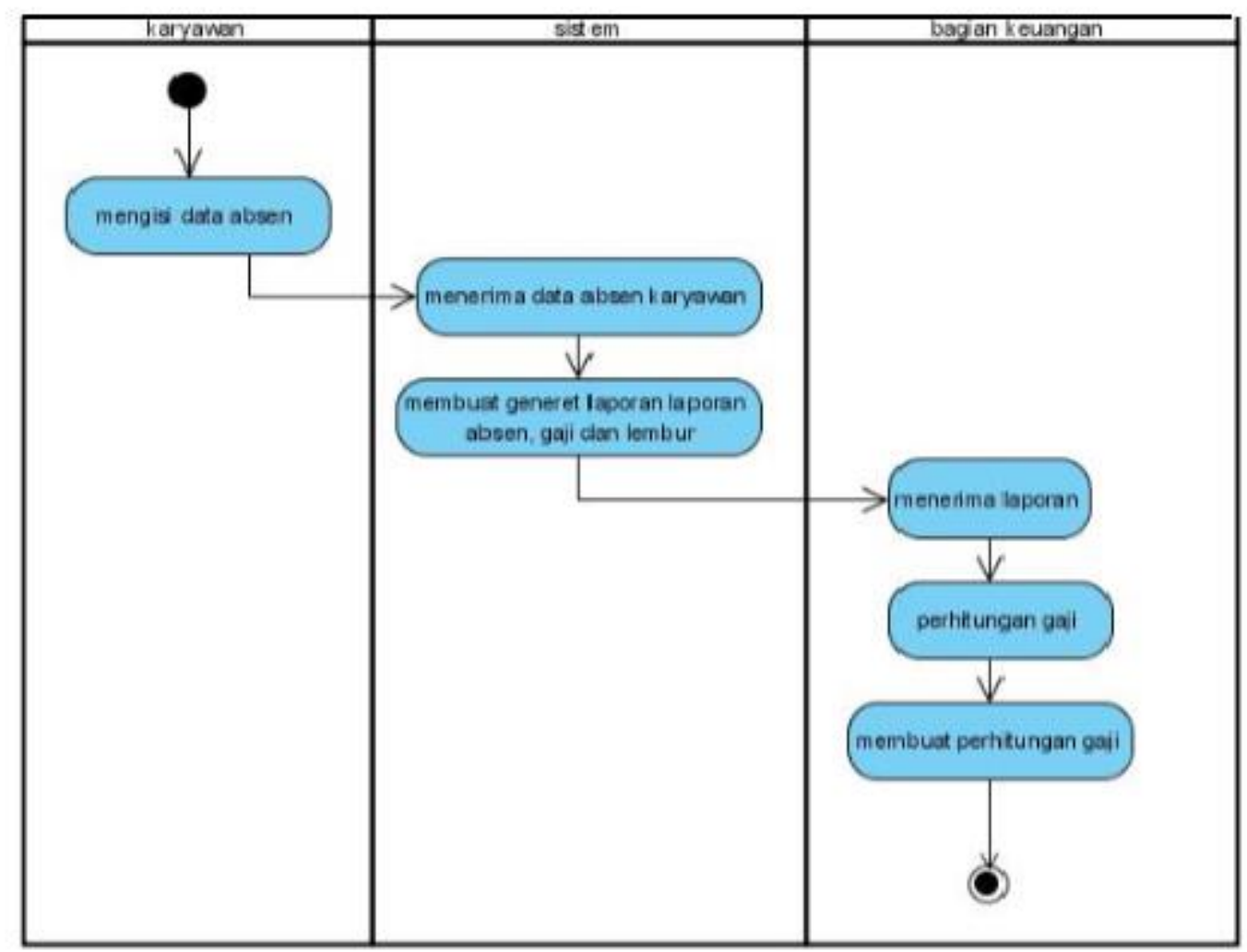

\section{Analisis Sistem Yang Diusulkan}

Gambar 2. Activity Diagram Sistem Yang Berjalan

Dalam menjalankan sistem yang diusulkan yaitu berupa aplikasi absensi kepegawaian berbasis web, maka untuk membuat dan menjalankannya membutuhkan elemen perangkat lunak (Software), perangkat keras (hardware) dan sumber daya manusia (brainware) sebagai berikut (Kami 1975):

1. Kebutuhan Perangkat Lunak (Software)

Perangkat lunak yang digunakan terkait pembuatan sistem dan penulisan diantaranya ialah :

Tabel 1. Software Yang Dibutuhkan

\begin{tabular}{|c|c|c|}
\hline No. & Jenis Software & Spesifikasi \\
\hline 1. & Operating System (OS) & Windows 10 Pro x64 bit \\
\hline
\end{tabular}




\begin{tabular}{|c|c|c|}
\hline 2. & Paket Software & XAMPP Version 5.6.30 \\
\hline 3. & Web Server & Apache 2.4.25 (Win 32) \\
\hline 4. & MySQL & MySQL Version 5.6.30 \\
\hline 5. & Browser & Google Chrome \\
\hline 6. & Code Editor & Notepad ++ \\
\hline
\end{tabular}

\section{Kebutuhan Perangkat Keras (Hardware)}

Perangkat keras yang digunakan terkait pembuatan sistem dan penulisan diantaranya ialah :

Tabel 2. Hardware Yang Dibutuhkan

\begin{tabular}{|c|c|c|}
\hline No. & Jenis Hardware & Spesifikasi \\
\hline 1. & Laptop Dell & Laptop Asus \\
\hline 2. & Processor & Intel Pentium Dual Core \\
\hline 2. & Memory RAM & DDR3 2 Gb \\
\hline 3. & Harddisk (HDD) & $320 \mathrm{~Gb}$ \\
\hline
\end{tabular}

\section{Perancangan User Interface}

Gambar 3. digunakan oleh aktor untuk login dan mengakses sistem. Karyawan dan HRD harus memasukan Username dan password yang valid agar dapat masuk ke dalam menu utama sistem tersebut.

SELAMAT DATANG DI PT

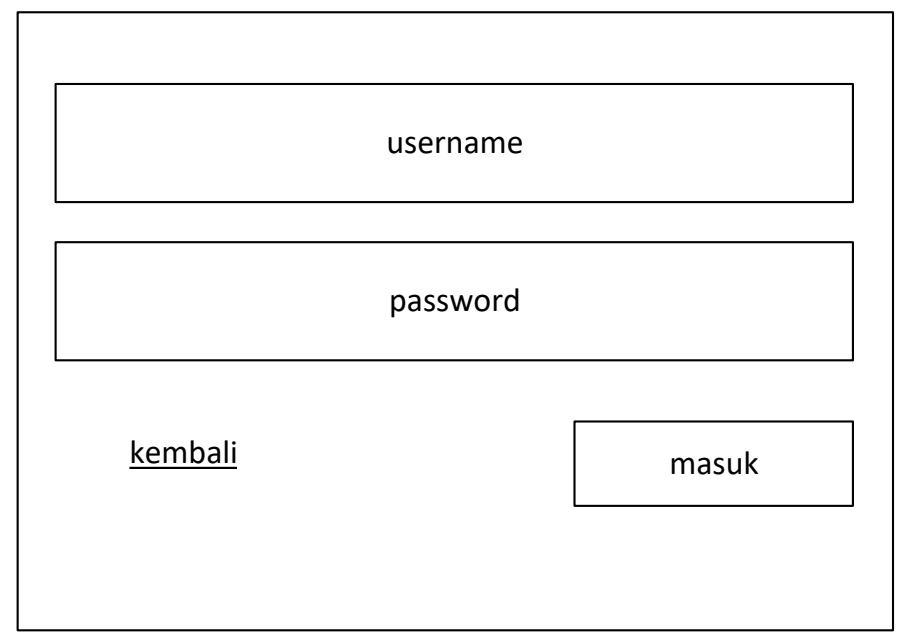

Gambar 3. Rancangan Tampilan Login User

Gambar 4. Menampilkan beberapa menu admin untuk mengelola absensi kepegawaian dimana di menu master terdapat profil, atur jam kerja, divisi, data karyawan dan absensi 
ETNIK: Jurnal Ekonomi - Teknik, 2021 volume 1 Issue No 3, Pages 219

SELAMAT DATANG DI PT

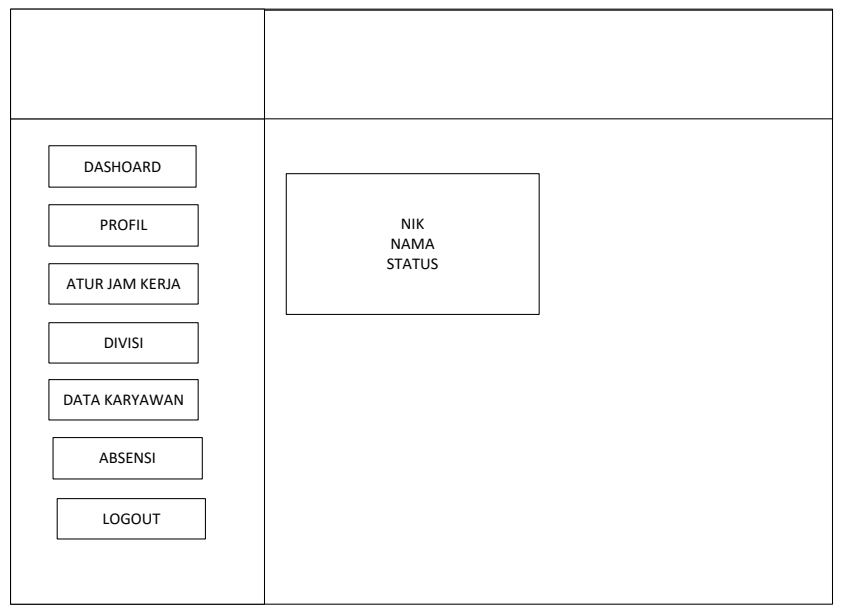

Gambar 4. Rancangan Halaman Admin

Gambar 5. digunakan oleh admin untuk login ke dalam sistem. Admin mengatur atur kerja karyawan.

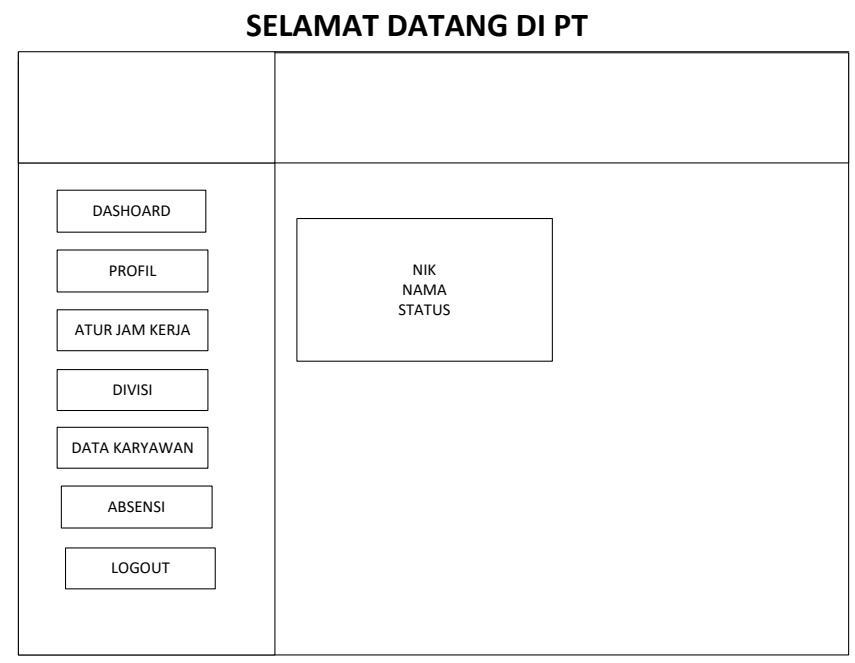

\section{Gambar 5. Rancangan Halaman Atur Jam Kerja}

Gambar 6. menampilkan halaman data karyawan agar bisa di cek siapa saja melakukan absensi pada saat jam kerja.

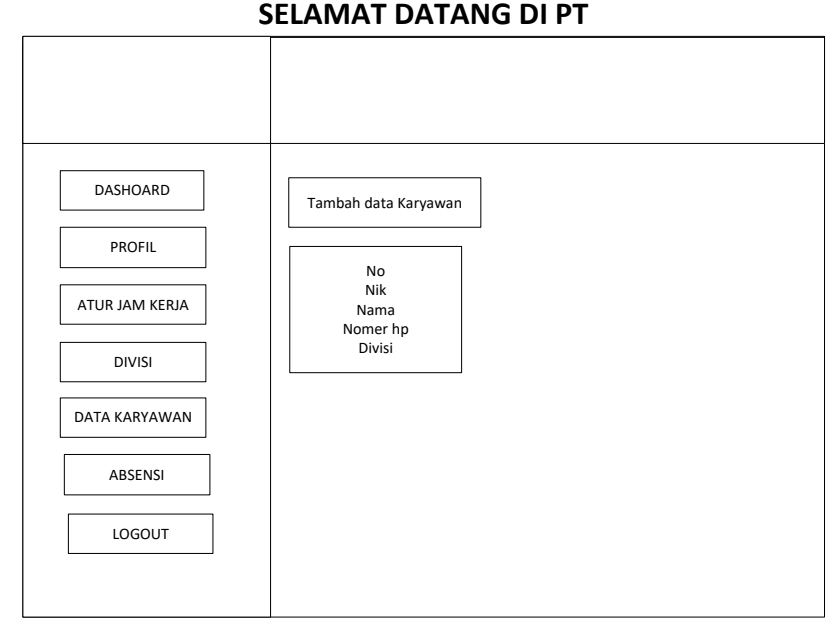

Gambar 6. Rancangan Halaman Data Karyawan 
Gambar 7. menampilkan beberapa menu pada divisi karyawan.

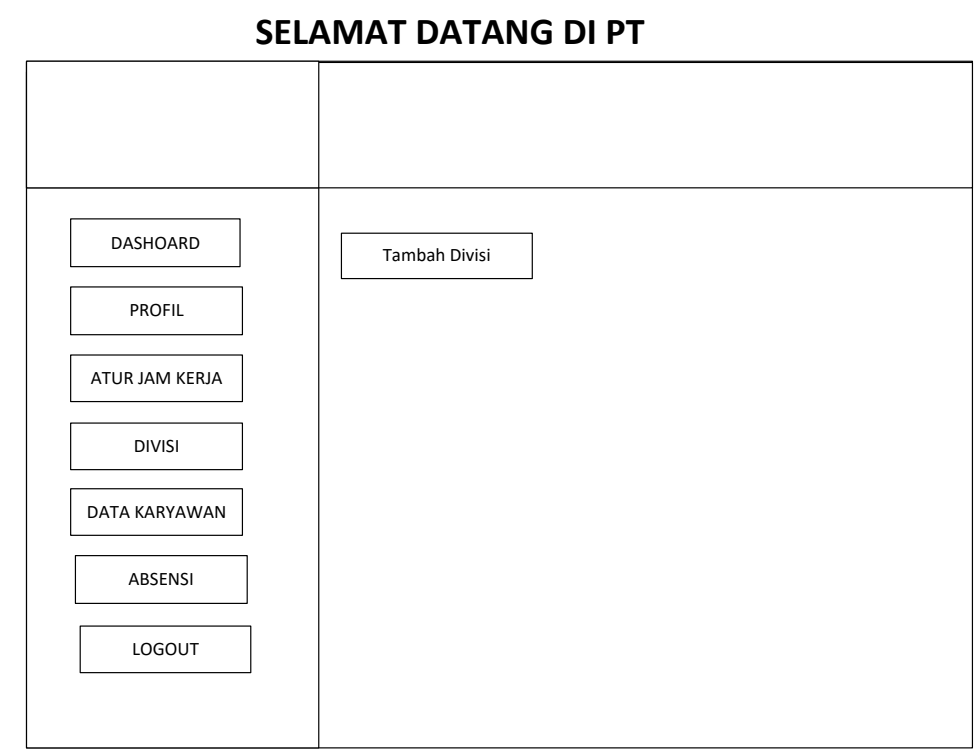

\section{Gambar 7. Rancangan Halaman Divisi}

\section{Implementasi User Interface}

Sesuai dengan perancangan user interface, maka implementasi sistemnya pun tidak jauh berbeda.

Gambar 8. berfungsi untuk menampilkan form login aktor yang akan digunakan untuk login dan mengakses menu utama. Aktor harus memasukan Username dan password yang valid agar dapat masuk ke dalam sistem..

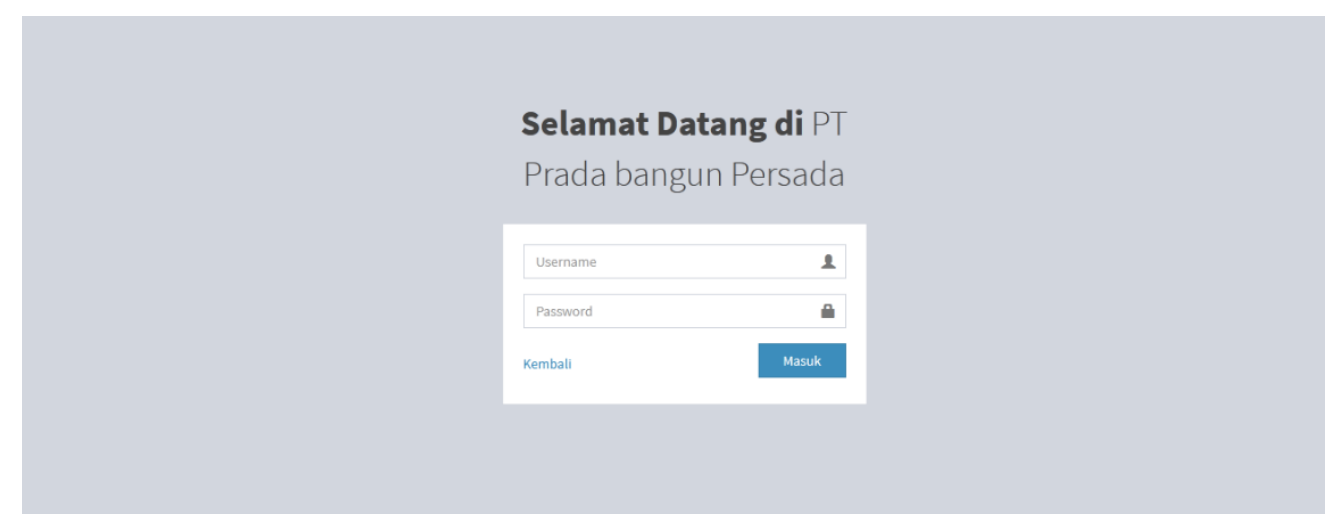

\section{Gambar 8. Tampilan Login Aktor}

Pada halaman admin dapat melihat halaman atur jam dimana bisa mengecek siapa saja - karyawankaryawan yang datang ke kantor. 


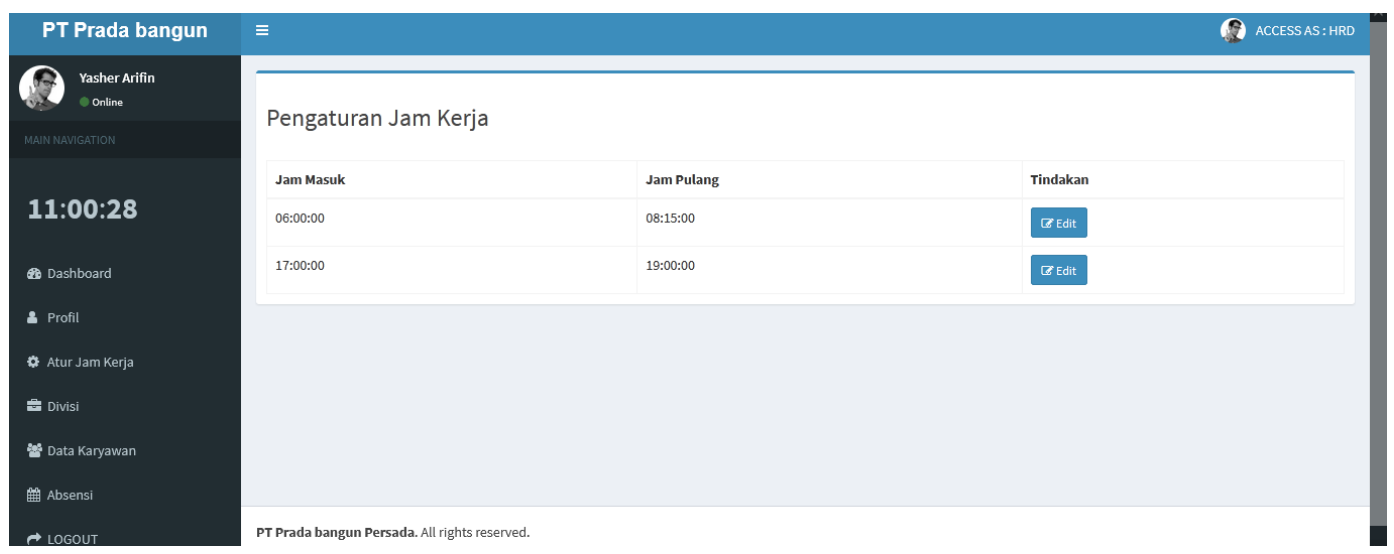

\section{Gambar 9. Tampilan Halaman Atur Jam Kerja}

Gambar 10. Di tampilan divisi ada beberapa nama-nama divisi misalnya marketing, IT, Accounting dan lain-lain

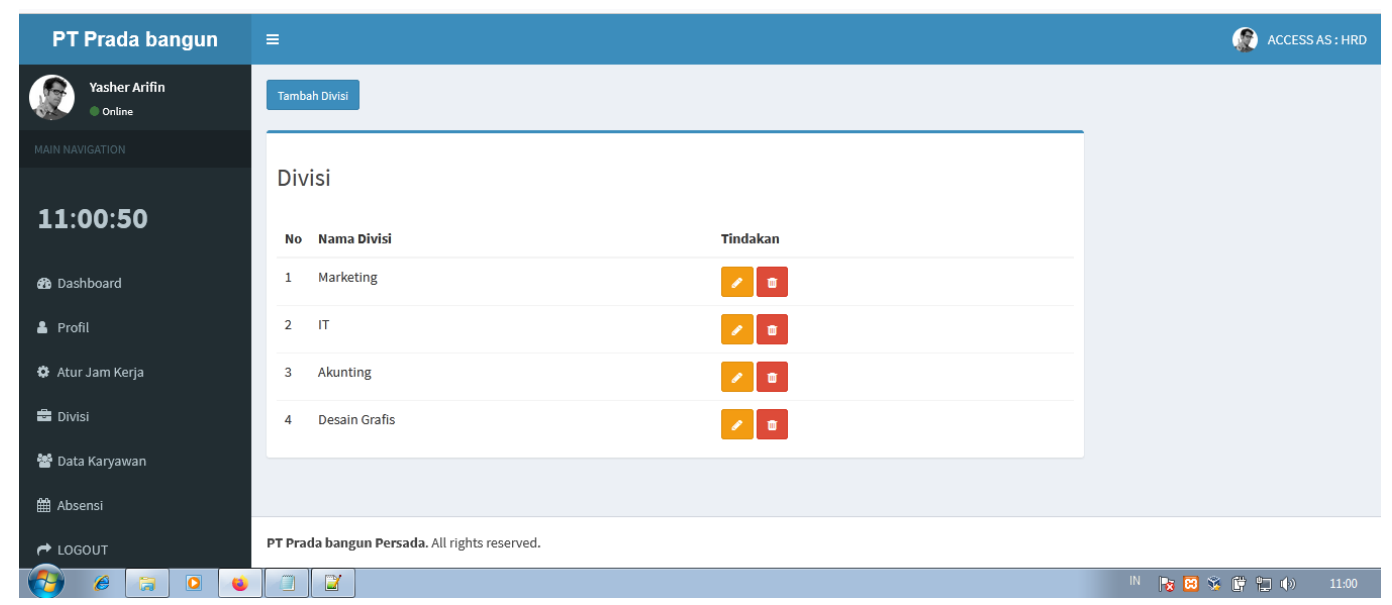

Gambar 10. Tampilan Halaman Divisi

Gambar 11. berfungsi untuk melihat data-data karyawan pada perusahaan tersebut.

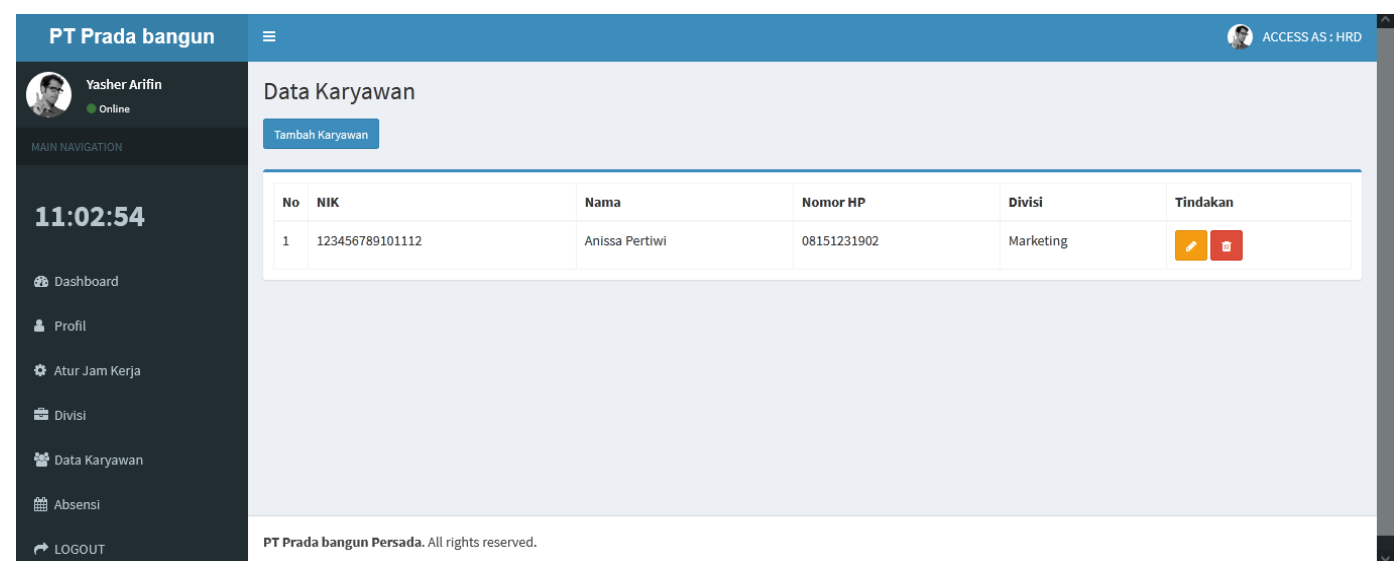

Gambar 11. Tampilan Halaman Data Karyawan

Gambar 12. Menampilkan tampilan halaman absensi setiap divisi. 


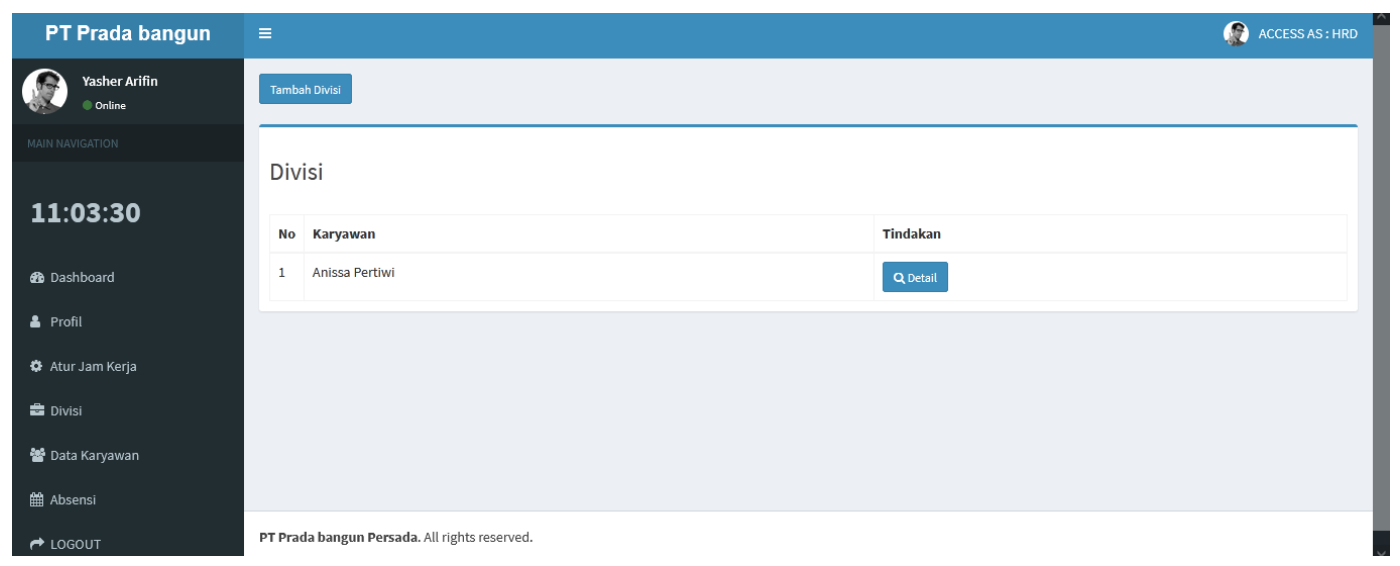

Gambar 12. Tampilan Halaman Absensi

\section{Integration and System Testing}

Pengujian dilakukan dengan metode Black Box Testing untuk mengetahui apakah fungsi-fungsi dan keluaran dari perangkat lunak sesuai dengan spesifikasi yang dibutuhkan dan sesuai dengan skenario yang telah dibuat (., Rusli, and Hasan 2021). Hasil pengujian yang dapat dilihat adalah sebagai berikut:

Tabel 3. Pengujian black box

\begin{tabular}{|l|l|l|l|}
\hline No & Pengujian & Tingkat Pengujian & Keterangan \\
\hline 1 & Login User & Integrasi & Black Box \\
\hline 2 & $\begin{array}{l}\text { Penambahan } \\
\text { data Karyawan }\end{array}$ & Integrasi & Black Box \\
\hline 3 & $\begin{array}{l}\text { Penambahan } \\
\text { Input Jabatan }\end{array}$ & Integrasi & Black Box \\
\hline 4 & Absen Masuk & Integrasi & Black Box \\
\hline 5 & Absen Keluar & Integrasi & Black Box \\
\hline 6 & $\begin{array}{l}\text { Desain } \\
\text { Halaman }\end{array}$ & Integrasi & Black Box \\
\hline 7 & $\begin{array}{l}\text { Desain } \\
\text { Halaman User }\end{array}$ & Integrasi & Black Box \\
\hline
\end{tabular}

\section{Maintenance (Pemeliharaan)}

Proses maintenance dilakukan dari sisi sistem (software) dan hardware. Tujuan dilakukannya maintenance untuk menjaga sistem tetap berjalan dengan baik dan masalah-masalah yang terjadi pada sistem bisa terdeteksi sehingga tidak menimbulkan masalah yang serius (Khotimin and Rachma 2020). 


\section{SIMPULAN}

Berdasarkan hasil penelitian dan pembahasan dalam penelitian ini, maka dapat disimpulkan bahwa sistem informasi absensi kepegawaian Berbasis Web pada PT. Prada bangun Persada yang sedang berjalan saat ini sangat kurang efektif dan efisien karena masih menggunakan absensi manual dengan dilakukannya pencatatan pada buku agenda absensi. Sistem informasi absensi pada Di perusahaan PT Prada Bangun Persada yang sedang berjalan belum mampu menghasilkan laporan secara tepat dan akurat. Untuk dapat merancang sistem informasi absensi kepegawaian Berbasis Web pada PT. Prada bangun Persada terkomputerisasi berbasis web, dimulai dari pembuatan diagram Unified Modelling Language (UML) sebagai awal perancangan sistem. Program yang digunakan dalam perancangan sistem menggunakan PHP sebagai bahasa pemrograman, serta database yang digunakan adalah MySQL.

\section{BIBLIOGRAFI}

. Uzmiati, Nurmala Rusli, and Syahril Hasan. 2021. "Sistem Informasi Pengelolaan Uang Komite Menggunakan Visual Foxpro Pada Sma Muhammadiyah 4 Tidore Kepulauan.” Jurnal Ilmiah ILKOMINFO - Ilmu Komputer \& Informatika 4(2): 122-33.

Agnitia LEstari, Mia, Muhamm Tabrani, and Surtika Ayumida. 2021. "Sistem Informasi Pengolahan Data Administrasi Kependudukan Pada Kantor Desa Pucung Karawang." Jurnal Interkom: Jurnal Publikasi Ilmiah Bidang Teknologi Informasi dan Komunikasi 13(3): 14-21.

Budi, Darmawan Setiya, Taghfirul Azhima Yoga Siswa, and Heri Abijono. 2017. "Analisis Pemilihan Penerapan Proyek Metodologi Pengembangan Rekayasa Perangkat Lunak." Teknika 5(1): 24-31.

Budiman, Haris. 2017. "Peran Teknologi Informasi Dan Komunikasi Dalam Pendidikan.” AlTadzkiyyah: Jurnal Pendidikan Islam 8(1): 31.

Devri Radistya. 2014. "Manajemen Risiko Industri Perkeretaapian Indonesia.” II: 1-76.

Fajri, Ricky Maulana. 2016. "Rancang Bangun Sistem Informasi Tracer Study Berbasis Web Studi Kasus Fakultas Ilmu Komputer Universitas Indo Global Mandiri.” Jurnal ilmiah informatika global 7(1): 1-9.

Kami, Takayasu. 1975. "Identification of Components in the Essential Oil of Hybridsorgo, a Forage Sorghum." Journal of Agricultural and Food Chemistry 23(4): 795-98.

Khotimin, Khotimin, and Nur Rachma. 2020. "Sistem Informasi Pendaftaran Online Komunitas Backpacker Langkah Khatulistiwa." Jurnal Sibernetika 5(1): 34-47. http://jurnas.stmikmj.ac.id/index.php/sibernetika/article/view/44.

Pratama, Lucky Adnin, Alusyanti Primawati, and Lusi Ariyani. 2019. "Perancangan Sistem Informasi Sirkulasi Buku Pada Perpustakaan SMP Negeri 103 Jakarta.” STRING (Satuan Tulisan Riset dan Inovasi Teknologi) 4(2): 227.

Purnama, Iwan et al. 2021. OR.

Sasmito, Ginanjar Wiro. 2017. "Penerapan Metode Waterfall Pada Desain Sistem Informasi Geografis Industri Kabupaten Tegal." Jurnal Informatika:Jurnal Pengembangan IT (JPIT) 2(1): 6-12. 